ISSN 1392-3196 / e-ISSN 2335-8947

Zemdirbyste-Agriculture, vol. 104, No. 4 (2017), p. 345-352

DOI 10.13080/z-a.2017.104.044

\title{
Pulsed electromagnetic field - a cultivation practice used to increase soybean seed germination and yield
}

\author{
Vojin ĐUKIĆ ${ }^{1}$, Zlatica MILADINOV ${ }^{1}$, Gordana DOZET ${ }^{2}$, Marija CVIJANOVIĆ ${ }^{3}$, \\ Mladen TATIĆ ${ }^{1}$, Jegor MILADINOVIĆ ${ }^{1}$, Svetlana BALEŠEVIĆ-TUBIĆ ${ }^{1}$ \\ Institute of Field and Vegetable Crops \\ Maksima Gorkog 30, 21000 Novi Sad, Serbia \\ E-mail: vojin.djukic@ifvens.ns.ac.rs \\ ${ }^{2}$ University John Naisbitt \\ Maršala Tita 39, 24300 Bačka Topola, Serbia \\ ${ }^{3}$ University of Belgrade \\ Nemanjina 6, 11080 Belgrade-Zemun, Serbia
}

\begin{abstract}
The aim of the research was to test the effect of pulsed electromagnetic field (PEMF) on soybean seed germination and yield depending on specific field conditions, years of study, exposure duration and frequency. Field trial was conducted on an experimental field of Institute of Field and Vegetable Crops in Novi Sad, Serbia in 2010-2013. Seeds of the soybean (Glycine hispida (Moench)) medium-early cultivar 'Valjevka' were exposed to the PEMF therapy using the impulse generator and strip. Low-frequency $(16,24,30$ and $72 \mathrm{~Hz})$ PEMF was used in the duration of $0,30,60$ and 90 minutes. Research results indicate that this method can increase seed germination up to $8.00 \%$ and yield by $960.5 \mathrm{~kg}$, or $21 \%$ in field conditions, which is a significant increase and a solid basis to introduce this practice, primarily in organic production with a very limited use of seed treatment preparations. However, the practice can have an inhibitory effect under an unfavourable combination of exposure duration and frequency. The obtained data were processed using the analysis of variance of three-factorial trials considering all years of study. Due to different meteorological conditions in the study years, analysis of variance was conducted for each year of study and correlations between the tested traits were examined.
\end{abstract}

Keywords: germination, Glycine hispida, pulsed electromagnetic waves, seed, yield.

\section{Introduction}

Soybean contains about $20 \%$ oil, which is susceptible to a deteriorative process due to inadequate grain storage, leading to high losses in the food industry. Depending upon the duration and conditions of storage, physical, chemical and biochemical alterations can occur in the soybeans (Kong et al., 2008). The major factors affecting the storability of soybeans include ambient relative humidity, seed initial moisture content, temperature and time duration of storage (Kong, Chang, 2009). Changes associated with seed deterioration are depletion in food reserve, increased enzyme activity, increased fat acidity and membrane permeability. As the catabolic changes continue with increasing age, the ability of the seed to germinate is reduced (Shelar et al., 2008). The low germination rate has been associated to early signs of membrane disorganization while the occurrence of seedling abnormalities (in the final stages of deterioration) is attributed to the significant death of tissues in different seed parts, particularly in meristematic tissues (Marcos-Filho, 2015). Seed quality is the basis of efficient crop production and farmers need such seeds for optimum yield production. Crop yield and resource use efficiency depend on successful plant establishment in the field, and it is the vigour of seeds that defines their ability to germinate and establish seedlings rapidly, uniformly and robustly across diverse environmental conditions (Finch-Savage, Bassel, 2016). Production technology uses different procedures for seed quality increase, aimed at improvements in seed germination and other seed properties. Physical treatments belong to the oldest known seed treatments. Physical methods have mostly been forgotten due to the success of chemical seed treatment products. Physical methods include different lasers, ultraviolet radiation (Hernández Aguilar et al., 2009), magnetic induction and electromagnetic waves (Abina et al., 2013; Lamanauskas et al., 2016), etc. In physical treatments, energy induced in cells creates the conditions suitable for molecular transformations, there

Please use the following format when citing the article:

Đukić V., Miladinov Z., Dozet G., Cvijanović M., Tatić M., Miladinović J., Balešević-Tubić S. 2017. Pulsed electromagnetic field - a cultivation practice used to increase soybean seed germination and yield. Zemdirbyste-Agriculture, 104 (4): $345-352$ DOI 10.13080/z-a.2017.104.044 
by supporting the development of special cell substances (Aladjadjiyan, 2007). Biophysical stimulation of seed and plant is performed through the increase in energetic balance, intensification of substance exchange, and activation of plant growth and yield (Vasilevski, 2003). Stimulation of electromagnetic pulses acts on structural change of water in the cell, which has a beneficial role on plants. The presence of electromagnetic field stimulates plant growth and development but at the same time, can act and repressive (Dicu, Pirsan, 2014). Exposure to electric, magnetic and electromagnetic waves showed positive or negative effects in many studies, influencing germination rate, germination percentage, seed weight, plant height, protein content, productivity, leaf surface, fruit weight and yield. Research results depend on the frequency, duration of exposure, seed traits and plant species. Proper combinations are necessary to achieve positive effects (Parsi, 2007).

The aim of the current research was to test how pulsed electromagnetic field (PEMF) affect germination and yield of soybean seed in field conditions, depending on the year of study, duration of exposure and frequency.

\section{Materials and methods}

The plant material is a soybean (Glycine hispida (Moench)) medium early cultivar 'Valjevka' developed at the Institute of Field and Vegetable Crops in Novi Sad, Serbia. The field trials were conducted during four growing seasons $(2010,2011,2012$ and 2013) at Rimski Šančevi experimental field $\left(45^{\circ} 20^{\prime} \mathrm{N} 19^{\circ} 51^{\prime}\right.$ E) near Novi Sad, Serbia. The trial was set up on humus soil type as a randomized block design with four replications under the conditions of dry farming. Plot size was $10 \mathrm{~m}^{2}$. Inter-row spacing of $50 \mathrm{~cm}$ and intra-row spacing of $5 \mathrm{~cm}$ was applied. Each year the plots were rotated with wheat (Triticum aestivum L.). Standard agricultural practices were conducted. Nitrogen $(\mathrm{N})$ fertilizer was applied in two rates: $30 \mathrm{~kg} \mathrm{ha}^{-1}$ (NPK 15:15:15, $200 \mathrm{~kg} \mathrm{ha}^{-1}$ ) before sowing and $34 \mathrm{~kg} \mathrm{ha}^{-1}$ (ammonium nitrate, N 34\%) before seedbed preparation (early April). There were no significant disease and insect attacks.

The seed was exposed to pulsed electromagnetic field (PEMF) using the impulse generator and strip. Lowfrequency $(16,24,30$ and $72 \mathrm{~Hz})$ PEMF in the duration of $0,30,60$ and 90 minutes were used. Immediately after exposure of the seed to PEMF, sowing was carried out at optimum time. After sprouting, seedlings were counted to determine the percentage of germinated seeds. Standard soybean cultivation practices were applied during vegetation. Harvesting was performed at the technological maturity stage, samples and moisture were measured with combine harvester for experimental plots with a small work operation (Wintersteiger elite) and yield was adjusted to $14 \%$ moisture. The analysis of results included meteorological data in the years of study.

Weather conditions. There was $684.4 \mathrm{~mm}$ of rainfall during vegetation in 2010, twice higher compared to the multi-annual average of $371.6 \mathrm{~mm}$. The average temperature of $18.43^{\circ} \mathrm{C}$ was slightly higher compared to the 46 -year average of $18.01^{\circ} \mathrm{C}$. There was only $210 \mathrm{~mm}$ of rainfall during vegetation in 2011, or lower by $161.1 \mathrm{~mm}$ compared to the 40 -year average, while the average temperature was $1.41^{\circ} \mathrm{C}$ higher. The temperature in 2012 was significantly higher compared to the multi- annual average, increased by $3.07^{\circ} \mathrm{C}$ in June, $3.7^{\circ} \mathrm{C}$ in July, $3.4^{\circ} \mathrm{C}$ in August and $2.97^{\circ} \mathrm{C}$ in September. There was a distinct lack of rainfall in June, July, August and September 2012, amounting to $226 \mathrm{~mm}$ of rainfall during vegetation. $448.2 \mathrm{~mm}$ of rainfall was recorded during vegetation in 2013 , which was $76.6 \mathrm{~mm}$ higher than the average. The temperature was $0.66^{\circ} \mathrm{C}$ higher compared to the multi-annual average (Figs. 1 and 2).

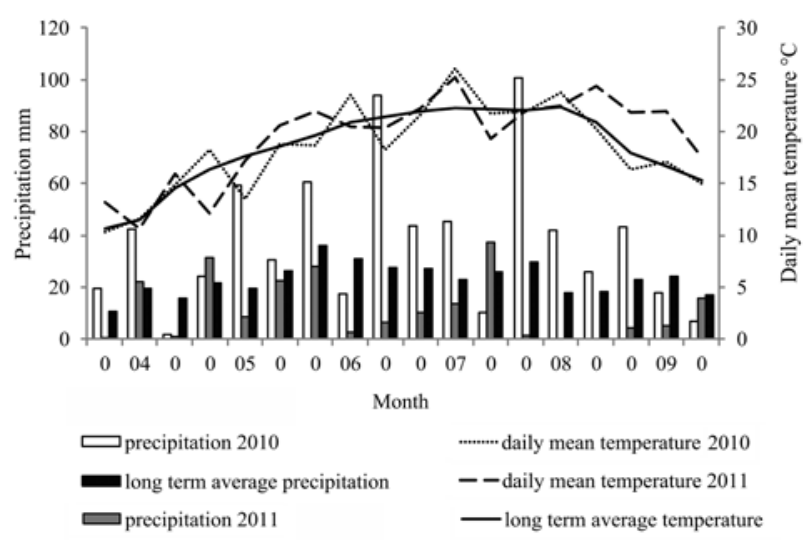

Figure 1. Ten-day period average temperature and precipitation for the 2010 and 2011, and long term average (1964-2010)

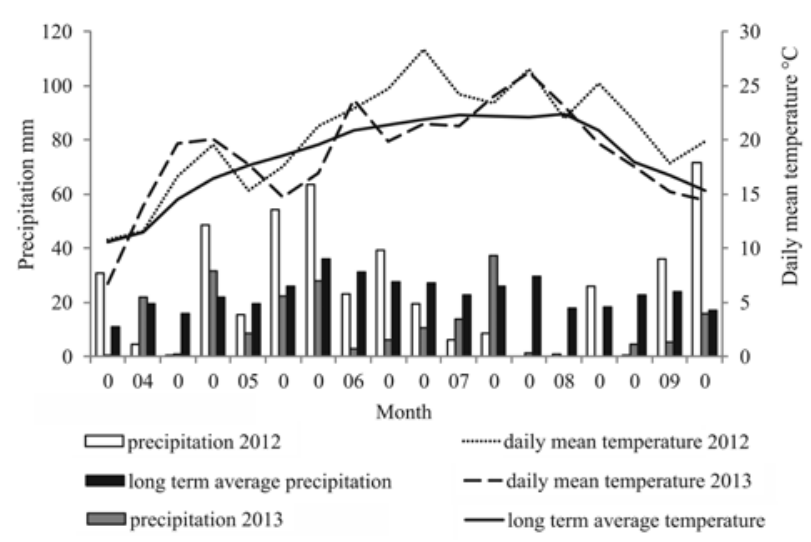

Figure 2. Ten-day period average temperature and precipitation for the 2012 and 2013, and long term average (1964-2010)

The obtained results were processed by the analysis of variance ( $A N O V A)$ for three-factorial trials in all years of study. Means were compared using Tuckey's multiple range test. Also determined were the correlations between the traits tested. All analyses were performed in STATISTICA 10.

\section{Results and discussion}

The effect of pulsed electromagnetic field (PEMF) on soybean seed germination. The effect of PEMF on soybean seed germination depended on the year (A), duration of exposure (B) and frequency (C), and year-by-duration of exposure interaction $(A \times B)$, year-by-frequency interaction $(\mathrm{A} \times \mathrm{C})$ and exposure interaction-by-frequency interaction $(B \times C)$ (Table 1). The main indicators of good seed quality are germination and vigour (Radzevičius et al., 2013). The number of plants per surface unit in field conditions is one of the major yield components (Liu et al., 2010). Seed marks the beginning of each plant production and therefore 
Table 1. The effect of pulsed electromagnetic field (PEMF) on soybean seed germination (\%)

\begin{tabular}{|c|c|c|c|c|c|c|c|c|}
\hline \multirow{2}{*}{$\begin{array}{l}\text { Year } \\
\text { (A) }\end{array}$} & \multirow{2}{*}{\multicolumn{2}{|c|}{$\begin{array}{l}\text { Time }(\mathrm{B}) \\
\min \end{array}$}} & \multicolumn{4}{|c|}{$\begin{array}{c}\text { Frequency }(\mathrm{C}) \\
\mathrm{Hz}\end{array}$} & \multirow{2}{*}{$\begin{array}{c}\text { Average } \\
\mathrm{A} \times \mathrm{B}\end{array}$} & \multirow{2}{*}{$\begin{array}{l}\text { Average } \\
\text { (A) }\end{array}$} \\
\hline & & & 16 & 24 & 30 & 72 & & \\
\hline \multirow{5}{*}{2010} & \multicolumn{2}{|c|}{0} & 87.00 & 87.00 & 87.00 & 87.00 & $87.00 \mathrm{c}$ & \\
\hline & \multicolumn{2}{|c|}{30} & 91.25 & 92.00 & 90.75 & 86.25 & $90.06 \mathrm{a}$ & \\
\hline & \multicolumn{2}{|c|}{60} & 90.25 & 88.75 & 87.75 & 92.75 & $89.88 \mathrm{ab}$ & $88.89 \mathrm{ab}$ \\
\hline & \multicolumn{2}{|c|}{90} & 90.75 & 88.00 & 89.00 & 86.75 & $88.63 \mathrm{bc}$ & \\
\hline & \multicolumn{2}{|c|}{ Average $\mathrm{A} \times \mathrm{C}$} & $89.81 \mathrm{a}$ & $88.94 \mathrm{ab}$ & $88.63 \mathrm{ab}$ & $88.19 \mathrm{~b}$ & & \\
\hline \multirow{5}{*}{2011} & \multicolumn{2}{|c|}{0} & 87.00 & 87.00 & 87.00 & 87.00 & $87.00 \mathrm{c}$ & \\
\hline & \multicolumn{2}{|c|}{30} & 92.00 & 94.50 & 91.75 & 86.00 & $91.06 \mathrm{a}$ & \\
\hline & \multicolumn{2}{|c|}{60} & 90.75 & 90.75 & 90.00 & 92.25 & $90.94 \mathrm{ab}$ & $89.67 \mathrm{a}$ \\
\hline & \multicolumn{2}{|c|}{90} & 91.00 & 89.00 & 90.75 & 88.00 & $89.69 \mathrm{~b}$ & \\
\hline & \multicolumn{2}{|c|}{ Average $\mathrm{A} \times \mathrm{C}$} & $90.19 \mathrm{ab}$ & $90.31 \mathrm{a}$ & $89.88 \mathrm{~b}$ & $88.31 \mathrm{~b}$ & & \\
\hline \multirow{5}{*}{2012} & \multicolumn{2}{|c|}{0} & 82.75 & 82.75 & 82.75 & 82.75 & $82.75 \mathrm{c}$ & \\
\hline & \multicolumn{2}{|c|}{30} & 87.25 & 88.25 & 88.00 & 79.25 & $85.69 \mathrm{ab}$ & \\
\hline & \multicolumn{2}{|c|}{60} & 87.00 & 84.75 & 86.25 & 90.00 & $87.00 \mathrm{a}$ & $84.88 \mathrm{c}$ \\
\hline & \multicolumn{2}{|c|}{90} & 85.00 & 83.25 & 85.00 & 83.00 & $84.06 \mathrm{bc}$ & \\
\hline & \multicolumn{2}{|c|}{ Average $\mathrm{A} \times \mathrm{C}$} & $85.50 \mathrm{a}$ & $84.75 \mathrm{ab}$ & $85.50 \mathrm{a}$ & $83.75 \mathrm{~b}$ & & \\
\hline \multirow{5}{*}{2013} & \multicolumn{2}{|c|}{0} & 85.00 & 85.00 & 85.00 & 85.00 & $85.00 \mathrm{~b}$ & \\
\hline & \multicolumn{2}{|c|}{30} & 93.00 & 92.75 & 91.75 & 82.25 & $89.94 \mathrm{a}$ & \\
\hline & \multirow{2}{*}{\multicolumn{2}{|c|}{$\begin{array}{l}60 \\
90\end{array}$}} & 90.00 & 88.00 & 87.25 & 92.75 & $89.50 \mathrm{a}$ & $88.09 \mathrm{~b}$ \\
\hline & & & 90.25 & 87.00 & 88.25 & 86.25 & $87.94 \mathrm{a}$ & \\
\hline & Averag & $\mathrm{A} \times \mathrm{C}$ & $89.56 \mathrm{a}$ & $88.19 \mathrm{ab}$ & $88.06 \mathrm{ab}$ & $86.56 \mathrm{~b}$ & & \\
\hline & & & $85.44 \mathrm{c}$ & $85.44 \mathrm{c}$ & $85.44 \mathrm{c}$ & 85.44 bc & & $85.44 \mathrm{c}$ \\
\hline Average & & & $90.88 \mathrm{a}$ & $91.88 \mathrm{a}$ & $90.56 \mathrm{a}$ & $83.44 \mathrm{c}$ & Average & $89.19 \mathrm{a}$ \\
\hline $\mathrm{B} \times \mathrm{C}$ & & & $89.50 \mathrm{ab}$ & $88.06 \mathrm{ab}$ & $87.81 \mathrm{~b}$ & $91.94 \mathrm{a}$ & B & $89.33 \mathrm{a}$ \\
\hline & & & $89.25 \mathrm{~b}$ & $86.81 \mathrm{bc}$ & $88.25 \mathrm{~b}$ & $86.00 \mathrm{~b}$ & & $87.58 \mathrm{~b}$ \\
\hline & Aver & ge $\mathrm{C}$ & $88.77 \mathrm{a}$ & $88.05 \mathrm{ab}$ & $88.02 \mathrm{ab}$ & $86.70 \mathrm{c}$ & & \\
\hline & Yea & (A) & Time (B) & Frequency $(\mathrm{C})$ & $\mathrm{A} \times \mathrm{B}$ & & & $\mathrm{B} \times \mathrm{C}$ \\
\hline Factory & & & $* *$ & $* *$ & $* *$ & & & $*$ \\
\hline & & & & 11 & & & & \\
\hline Average & $\mathrm{LSD}_{0.05}$ & $\mathrm{LSD}_{0.01}$ & $\mathrm{LSD}_{0.05}$ & $\mathrm{LSD}_{0.01}$ & $\mathrm{LSD}_{0.05}$ & $\mathrm{LSD}_{0.01}$ & $\mathrm{LSD}_{0.05}$ & $\mathrm{LSD}_{0.01}$ \\
\hline $\mathrm{B}$ & 1.30 & 1.82 & 1.50 & 2.10 & 1.71 & 2.40 & 1.17 & 1.65 \\
\hline $\mathrm{C}$ & 0.74 & 1.00 & 0.82 & 1.10 & 0.85 & 1.13 & 0.91 & 1.22 \\
\hline $\mathrm{B} \times \mathrm{C}$ & 1.48 & 1.99 & 1.64 & 2.20 & 1.69 & 2.27 & 1.82 & 2.44 \\
\hline
\end{tabular}

$* *$ - significance at $0.01, *$ - significance at 0.05 probability level

ensuring its quality is the priority of modern seed science and a prerequisite for obtaining high yields of all plant species (Milošević et al., 2010). Explicit seed treatments before sowing can improve germination in field conditions (Miladinov et al., 2014).

Application of a suitable pre-sowing treatment is therefore necessary in order to reduce sowing risks under field conditions, especially under low moisture conditions, as well as secure the optimum planting density and obtain high yields. One of the pre-sowing treatments in use is PEMF. Research results show that the application of this method increases seed germination in field conditions up to $8.00 \%$.

The best effect was achieved in 2013, with a germination increase by $3.09 \%$. In average this presowing treatment gave higher seed germination by $1.20 \%$ in 2013 compared to 2010. In 2011 and 2012, there was an increase in quality by $2.67 \%$ and $2.13 \%$, respectively.

The average best duration of exposure was 60 minutes considering all years of study and all frequencies. Germination increased by $3.89 \%$ compared to untreated seed. A positive effect was also achieved using shorter exposure time. The increase in quality was $3.75 \%$, which is higher by $1.75 \%$, i.e. $1.51 \%$ compared to efficiency of 90-minute exposure time. The lowest frequency of $16 \mathrm{~Hz}$ had the most positive effects with the improvement of $3.33 \%$. Increased frequency caused lower effects, i.e. $72 \mathrm{~Hz}$ frequency resulted in $1.26 \%$ improvement, or $2.07 \%$ less compared to the best effect. There was no significant difference between the $24 \mathrm{~Hz}$ and $30 \mathrm{~Hz}$ frequency, and the quality increased by $2.61 \%$ and $2.58 \%$, respectively.

Ortiz et al. (2015) determined a positive effect of PEMF on maize seed germination, seedling growth, fresh mass accumulation and dry matter content, chlorophyll $a$ and $b$ content, and total chlorophyll. They defined the application of electromagnetic waves as a breakthrough in the improvement of seed vigour, seedling growth and reduced time of seed dormancy (Ortiz et al., 2015). Furthermore, PEMF have been found to promote germination and improve early growth characteristics of oregano seedlings (Bilalis et al., 2012 b). Treatments applied on pea seed led to increase in germination by $2.6 \%$, seedling length by $5.5 \%$ and root by $18.6 \%$, as well as increase in plant mass by $6.9 \%$ compared to the control (Palov et al., 2013). Seed germination increase 
can come as a result of more intensive germination due to higher nutrient intake and better water absorption during electromagnetic wave treatment (Moon, Chung, 2000). Besides the favourable effect on seed germination, some authors detected a positive effect on seed yield. The effect of the treatment depends on the year, exposure duration and frequency, which is in accordance with the results of Radzevičius et al. (2013) who also included hybrid type and geomagnetic conditions as prerequisites for the success of this presowing treatment.

However, significant differences occurred in analysis of the correlation between the year of study and exposure time. In 2012, 60-minute exposure time improved germination by $4.25 \%$, while in all other years of study the best result was achieved using 30-minute exposure time. The increase percentage ranged between $3.06 \%$ and $4.94 \%$. Regarding the correlation between frequency and year of study, the best effects were obtained using the $16 \mathrm{~Hz}$ frequency in the three years of study, while slightly higher effects were obtained in 2011 using the $24 \mathrm{~Hz}$ frequency. The increase ranged from $2.75 \%$ to $4.56 \%$ when the lowest PEMF frequency was used for seed treatment. Direct correlation was observed between exposure time and frequency. Exposure time of 30-minute at the $24 \mathrm{~Hz}$ frequency provided an increase in soybean seed quality by $6.44 \%$. Exposure time of 60 -minute at $72 \mathrm{~Hz}$ frequency improved soybean seed germination by $6.50 \%$. The longest exposure time gave the best results with $3.81 \%$ increase at the lowest frequency. Regarding the analysis of each year of study, the highest effect was obtained using the $72 \mathrm{~Hz}$ frequency in 2010, increasing

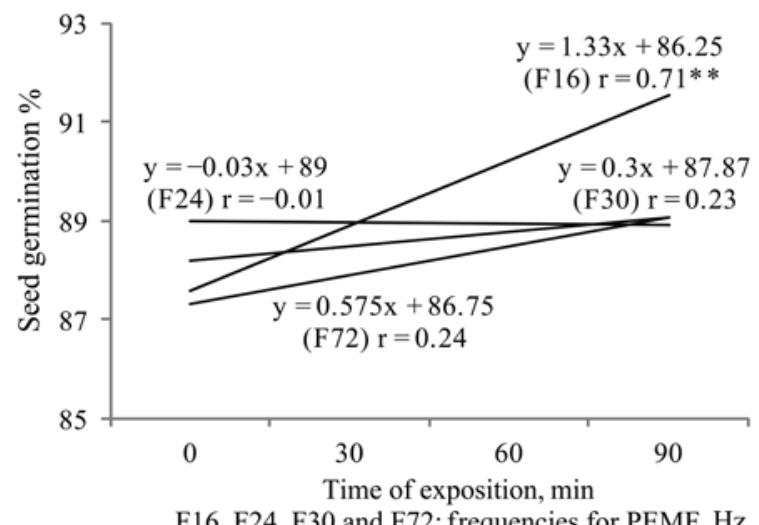

Figure 3. The effect of pulsed electromagnetic waves on soybean seed germination in 2010

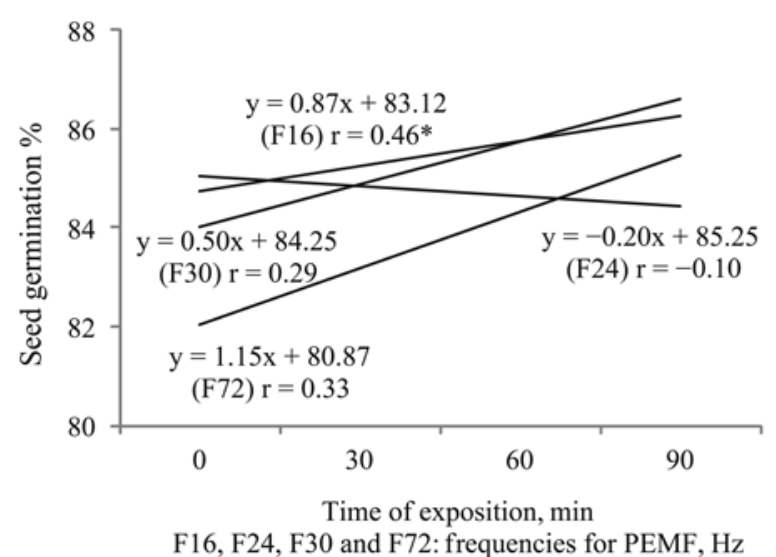

Figure 5. The effect of pulsed electromagnetic waves on soybean seed germination in 2012 germination by $5.75 \%$. Both longer and shorter exposure time negatively affected quality. In 2011, all combinations had a positive effect except the frequency of $72 \mathrm{~Hz}$ during the 30-minute exposure time. The highest increase of $7.5 \%$ was observed in that particular year. The frequency of $72 \mathrm{~Hz}$ during 30-minute exposure time in 2012 led to the decrease in quality by $3.5 \%$, which was the highest recorded effect. The frequency of $72 \mathrm{~Hz}$ applied in the duration of 60 -minutes resulted in $7.25 \%$ increase in 2012, while the use of $16 \mathrm{~Hz}$ frequency during 30-minute increased the quality by $8 \%$ in 2013 . Linear regression was applied in order to test the effects of exposure time and frequency on soybean seed germination in field conditions, across all years of study. Considering all years of study, the strongest linear correlation was observed at the frequency of $16 \mathrm{~Hz}$, meaning that the increase in exposure time at this frequency had desired effects on soybean seed germination. The intensity of PEMF is an important factor for success of this presowing treatment. Activating plant growth and germination can be accelerated by using an optimum frequency (Aladjadjiyan, 2007). The results of Macovei et al. (2014) showed that different frequencies can have a stimulating or an inhibitory effect. The research indicates that a wave length can positively influence sprouting and root length of one hybrid, whereas it can have repressive effects on another hybrid (Dicu, Pirsan, 2014).

The coefficient frequency ranged between 0.46 and 0.71 depending on the year (Figs. 3-6). There was no correlation between the frequency of $24 \mathrm{~Hz}$ and exposure time in any of the study years. Strong linear

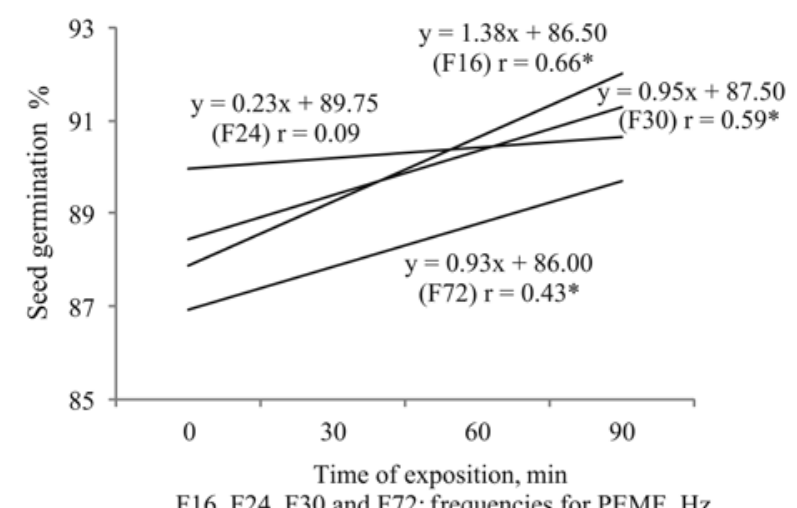

Figure 4. The effect of pulsed electromagnetic waves on soybean seed germination in 2011

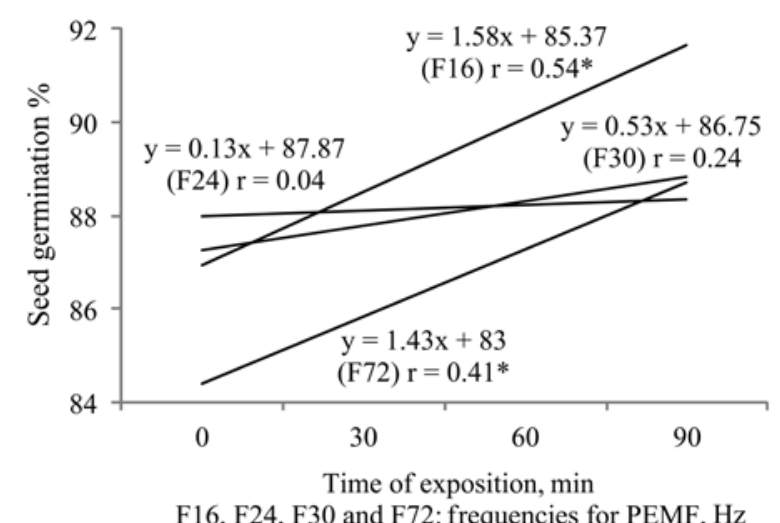

Figure 6. The effect of pulsed electromagnetic waves on soybean seed germination in 2013 
correlation was observed in $2010\left(r^{2}=0.71\right)$ at the frequency of $16 \mathrm{~Hz}$. Therefore, the increase in exposure time resulted in improved seed germination. In 2011, a significant correlation occurred between frequency and exposure time, with the exception of $24 \mathrm{~Hz}$ lacking any interdependence. The highest linear correlation occurred at the frequency of $16 \mathrm{~Hz}\left(r^{2}=0.66\right)$. The highlight lowest linear correlation was observed in 2012, compared to all other years of study, while the regression coefficient increased to 0.54 in 2013.

Besides PEMF intensity, exposure duration can also have significant effects. Suitable combination between exposure duration and frequency is needed in order to obtain the desired results. Specific traits of the treated plant species should also be taken into account. According to the study, soybean seed germination was most positively affected by frequency of $16 \mathrm{~Hz}$ with exposure time of 30 minutes.

The effect of PEMF on soybean seed yield. Yield increased by $960.5 \mathrm{~kg}$, i.e. $21 \%$ using PEMF frequency $16 \mathrm{~Hz}$ and 30-minute exposure, which is a significant increase and a solid basis to introduce this pre-sowing treatment, primarily in organic production where the application of seed treatment preparations is highly limited. Besides the positive effects on yield, Bilalis et al. (2012 a) determined a positive effect of this treatment on chlorophyll content, leaf area, plant fresh and dry weight, and finally yield in maize. The effect of PEMF on soybean seed yield depended on the year of study, exposure duration and frequency. The best effect was obtained in 2010, with increased yield up to $191.17 \mathrm{~kg}$, i.e. $139.44 \mathrm{~kg}$ more than in 2011. In 2013 and 2012, seed treatment using PEMF led to a yield increase of $382.2 \mathrm{~kg}$, i.e. $443.7 \mathrm{~kg}$ (Table 2). On average, the best exposure duration was 60-minutes considering all years of study and frequencies. Yield increased by $239.49 \mathrm{~kg}$ compared to untreated seed. Shorter exposure time also gave positive results. Exposure of soybean seed to PEMF during 30-minute exposure resulted in yield increase of $148.42 \mathrm{~kg}$. The lowest effect was obtained in the longest exposure time, with the increase of 89.07 or $150.42 \mathrm{~kg}$ lower compared to the best treatment. The best effect on yield was obtained by the use of PEMF at $24 \mathrm{~Hz}$ frequency, resulting in yield increase of $239.91 \mathrm{~kg}$. That pretreatment of PEMF plays important roles in improvement of crop productivity of soybean through the enhancement of protein, mineral accumulation and enzyme activities, which leads to increase yield (Radhakrishnan, Kumari, 2012). Seed treatment with lower frequencies resulted in yield increase of $199.82 \mathrm{~kg}$. Higher frequencies caused the opposite effect of this presowing treatment, thereby increasing the yield by $34.3 \mathrm{~kg}$ at the $30 \mathrm{~Hz}$ frequency.

Table 2. The effect of pulsed electromagnetic waves on soybean seed yield $\left(\mathrm{kg} \mathrm{ha}^{-1}\right)$

\begin{tabular}{|c|c|c|c|c|c|c|c|c|}
\hline \multirow{2}{*}{$\begin{array}{l}\text { Year } \\
\text { (A) }\end{array}$} & \multirow{2}{*}{\multicolumn{2}{|c|}{$\begin{array}{l}\text { Time }(\mathrm{B}) \\
\min \end{array}$}} & \multicolumn{4}{|c|}{$\begin{array}{c}\text { Frequency }(\mathrm{C}) \\
\mathrm{Hz}\end{array}$} & \multirow{2}{*}{$\begin{array}{c}\text { Average } \\
\mathrm{A} \times \mathrm{B}\end{array}$} & \multirow{2}{*}{$\begin{array}{c}\text { Average } \\
\text { A }\end{array}$} \\
\hline & & & 16 & 24 & 30 & 72 & & \\
\hline \multirow{5}{*}{2010} & \multicolumn{2}{|c|}{0} & 3703.8 & 3703.8 & 3703.8 & 3703.8 & \multirow{5}{*}{$\begin{array}{c}3703.75 \mathrm{~b} \\
3926.19 \mathrm{a} \\
4067.94 \mathrm{a} \\
3882.00 \\
\mathrm{ab}\end{array}$} & \multirow{5}{*}{$3894.97 \mathrm{a}$} \\
\hline & \multicolumn{2}{|c|}{30} & 4664.3 & 3762.5 & 3596.0 & 3682.0 & & \\
\hline & \multicolumn{2}{|c|}{60} & 3622.5 & 4494.3 & 4288.3 & 3866.8 & & \\
\hline & \multicolumn{2}{|c|}{90} & 3941.3 & 4366.8 & 3671.0 & 3549.0 & & \\
\hline & \multicolumn{2}{|c|}{ Average $\mathrm{A} \times \mathrm{C}$} & $3982.94 \mathrm{a}$ & $4081.81 \mathrm{a}$ & $3814.75 \mathrm{ab}$ & $3700.38 \mathrm{~b}$ & & \\
\hline \multirow{5}{*}{2011} & \multicolumn{2}{|c|}{0} & 3641.0 & 3641.0 & 3641.0 & 3641.0 & \multirow{2}{*}{$\begin{array}{l}3641.00 \mathrm{a} \\
3725.88 \mathrm{a}\end{array}$} & \multirow{5}{*}{$3692.75 \mathrm{ab}$} \\
\hline & & & 4113.5 & 3658.3 & 3523.8 & 3608.0 & & \\
\hline & & & 3546.3 & 3965.8 & 3684.3 & 3796.3 & $3748.13 \mathrm{a}$ & \\
\hline & & & 3809.5 & 3965.8 & 3536.3 & 3312.5 & \multirow[t]{2}{*}{$3656.00 \mathrm{a}$} & \\
\hline & Avera & $\mathrm{A} \times \mathrm{C}$ & $3777.56 \mathrm{a}$ & $3807.69 \mathrm{a}$ & $3596.31 \mathrm{~b}$ & $3589.44 \mathrm{~b}$ & & \\
\hline \multirow{5}{*}{2012} & \multicolumn{2}{|c|}{0} & 2325.3 & 2325.3 & 2325.3 & 2325.3 & \multirow{5}{*}{$\begin{array}{l}2325.25 \mathrm{a} \\
2449.88 \mathrm{a} \\
2545.94 \mathrm{a} \\
2429.50 \mathrm{a}\end{array}$} & \multirow{5}{*}{$2437.64 \mathrm{c}$} \\
\hline & & & 2769.0 & 2405.3 & 2284.3 & 2341.0 & & \\
\hline & & & 2363.5 & 2652.8 & 2613.5 & 2554.0 & & \\
\hline & & & 2600.3 & 2682.3 & 2274.0 & 2161.5 & & \\
\hline & Avera & $\mathrm{A} \times \mathrm{C}$ & $2514.50 \mathrm{a}$ & $2516.38 \mathrm{a}$ & $2374.25 \mathrm{~b}$ & $2345.44 \mathrm{~b}$ & & \\
\hline \multirow{5}{*}{2013} & \multicolumn{2}{|c|}{0} & 3430.3 & 3430.3 & 3430.3 & 3430.3 & \multirow{5}{*}{$\begin{array}{l}3430.25 \mathrm{a} \\
3592.00 \mathrm{a} \\
3696.19 \mathrm{a} \\
3489.00 \mathrm{a}\end{array}$} & \multirow{5}{*}{$3551.86 \mathrm{~b}$} \\
\hline & & & 3812.5 & 3624.3 & 3300.0 & 3631.3 & & \\
\hline & & & 3525.3 & 3791.3 & 3768.3 & 3700.0 & & \\
\hline & & & 3730.0 & 3770.3 & 3310.0 & 3145.8 & & \\
\hline & Avera & $\mathrm{A} \times \mathrm{C}$ & $3624.50 \mathrm{a}$ & $3654.00 \mathrm{a}$ & $3452.13 \mathrm{~b}$ & $3476.81 \mathrm{~b}$ & & \\
\hline \multirow{5}{*}{$\begin{array}{c}\text { Average } \\
\mathrm{B} \times \mathrm{C}\end{array}$} & \multicolumn{2}{|c|}{0} & $3275.06 \mathrm{c}$ & $3275.06 \mathrm{~b}$ & $3275.06 \mathrm{~b}$ & $3275.06 \mathrm{~b}$ & & $3275.06 \mathrm{~b}$ \\
\hline & & & $3839.81 \mathrm{a}$ & $3362.56 \mathrm{~b}$ & $3176.00 \mathrm{~b}$ & $3315.56 \mathrm{ab}$ & & $3423.48 \mathrm{ab}$ \\
\hline & & & $3264.38 \mathrm{c}$ & $3726.00 \mathrm{a}$ & $3588.56 \mathrm{a}$ & $3479.25 \mathrm{a}$ & Average & $3514.55 \mathrm{a}$ \\
\hline & & & $3520.25 \mathrm{~b}$ & $3696.25 \mathrm{a}$ & $3197.81 \mathrm{~b}$ & $3042.19 \mathrm{bc}$ & B & $3364.13 \mathrm{ab}$ \\
\hline & Ave & $\mathrm{C}$ & $3474.88 \mathrm{ab}$ & $3514.97 \mathrm{a}$ & $3309.36 \mathrm{ab}$ & $3278.02 \mathrm{~b}$ & & \\
\hline & $\mathrm{Ye}$ & A) & Time (B) & Frequency $(\mathrm{C})$ & $\mathrm{A} \times \mathrm{B}$ & $\mathrm{A} \times$ & & $\mathrm{B} \times \mathrm{C}$ \\
\hline ractory & & & $*$ & $* *$ & $*$ & * & & $*$ \\
\hline & & & & 11 & & & & 13 \\
\hline Factors & $\mathrm{LSD}_{0.05}$ & $\mathrm{LSD}_{0.01}$ & $\mathrm{LSD}_{0.05}$ & $\mathrm{LSD}_{0.01}$ & $\mathrm{LSD}_{0.05}$ & $\mathrm{LSD}_{0.01}$ & $\mathrm{LSD}_{0.05}$ & $\mathrm{LSD}_{0.01}$ \\
\hline $\mathrm{B}$ & 190.35 & 270.12 & 270.86 & 390.05 & 250.42 & 350.64 & 250.74 & 360.09 \\
\hline $\mathrm{C}$ & 90.79 & 130.12 & 210.49 & 280.82 & 170.75 & 230.80 & 140.52 & 190.47 \\
\hline $\mathrm{B} \times \mathrm{C}$ & 190.57 & 260.24 & 420.98 & 570.64 & 350.49 & 470.59 & 290.04 & 380.94 \\
\hline
\end{tabular}

** - significance at $0.01, *$ - significance at 0.05 probability level 
A large difference was observed considering the effect of the year of study on exposure time. The best results were obtained by seed exposure time of 60 -minutes in all the years of study. In 2010 , yield increase of $364.19 \mathrm{~kg}$ was observed, i.e. $257.06 \mathrm{~kg}$ more compared to 2011 . Yield increase in 2012 and 2013 was 443.7 and $382.2 \mathrm{~kg}$, respectively.

Analysis of the effect of frequency across the years of study revealed that the best effect was obtained by using PEMF at the frequency of $24 \mathrm{~Hz}$ in all years of study. The increase in 2010 was $378.01 \mathrm{~kg}$, which was $211.32 \mathrm{~kg}$ higher than in 2011. In 2012 and 2013, the yield increased by 191.8 and $223.7 \mathrm{~kg}$. Analysis of correlation between the effect of exposure time and the frequency revealed the dependence of the effect of frequency on exposure time. Exposure time of 30-minute at $16 \mathrm{~Hz}$ resulted in yield increase of $564.75 \mathrm{~kg}$. Exposure time of 60-minute at all frequencies resulted in the highest yield increase, ranging between 204.19 and $450.94 \mathrm{~kg}$. Analysis of each year of study showed that the best effect on yield was obtained using the frequency of $16 \mathrm{~Hz}$ and exposure time of 30 minutes in all the years of study, resulting in yield increase of 382.2 to $960.5 \mathrm{~kg}$. Parsi (2007) concluded that these treatments are used to obtain organic products, increase morphological traits and yield, and get better quality of the product, while the results depend on seed traits, plant species, frequency, and exposure time. Research results show the larger effect of this treatment in the years with higher rainfall during

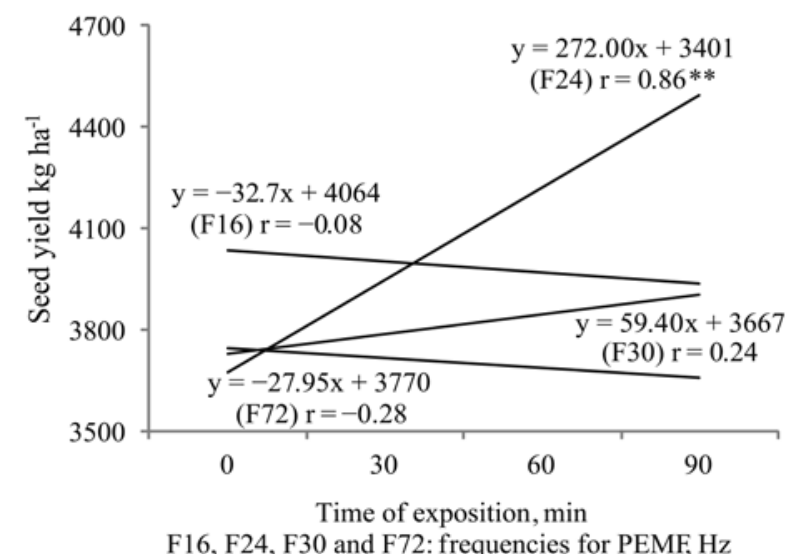

Figure 7. The effect of pulsed electromagnetic waves on soybean seed yield in 2010

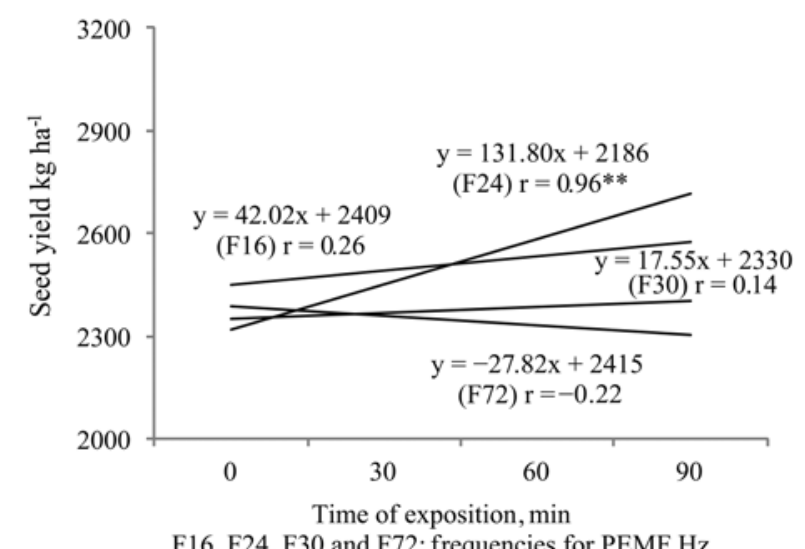

Figure 9. The effect of pulsed electromagnetic waves on soybean seed yield in 2012 vegetation. However, significant increase in germination and yield was obtained under lower moisture level.

The highest linear correlation was determined when frequency of $24 \mathrm{~Hz}$ was used, for all years of study, which means that favourable effects on yield are obtained by increase in the duration of soybean seed exposure under the given frequency. Correlation coefficient ranged between 0.86 and 0.96 , i.e. the increase in exposure at this frequency significantly increased yield (Figs. 7-10). In 2010, the lowest correlation coefficient was observed compared to all the study years $\left(r^{2}=0.86\right)$ while the longest exposure caused negative correlation $\left(r^{2}=-0.28\right)$. In 2011, the frequency of $72 \mathrm{~Hz}$ gave significant satisfying results. Correlation coefficient was 0.91 . The highest linear correlation was observed in 2012 $\left(r^{2}=0.96\right)$. This is in accordance with the results of Parsi (2007), outlining that, besides seed traits, the effect on yield and quality depends on plant species, exposure time and frequency. Magnetic and electromagnetic treatments are being used in agriculture, as a noninvasive technique, to improve the germination of seeds and increase crops and yields (Martínez et al., 2009). The biological and molecular mechanisms underlying the beneficial effects of radiation are still debated but several clues have already been proposed. Several authors pointed at reactive oxygen species (ROS) produced in the seed as key regulators of the response to $\gamma$-rays, since they act as signalling molecules, triggering and amplifying stress and antioxidant responses. Consequently, irradiated

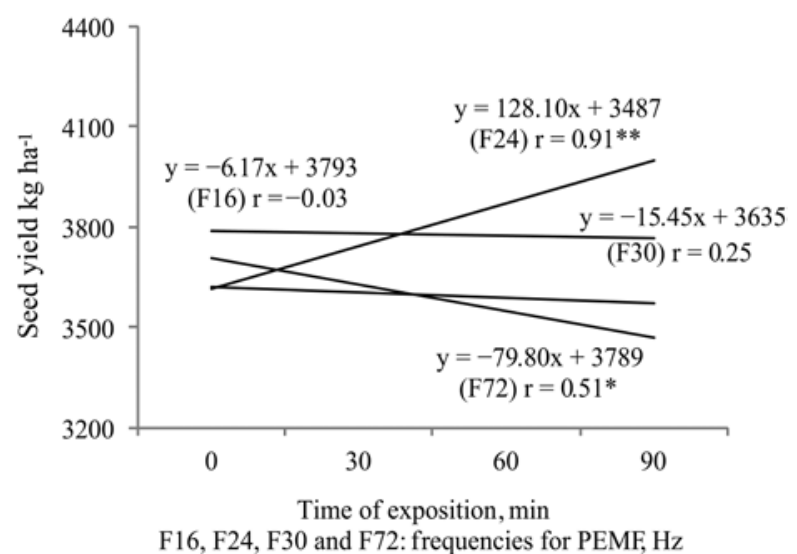

Figure 8. The effect of pulsed electromagnetic waves on soybean seed yield in 2011

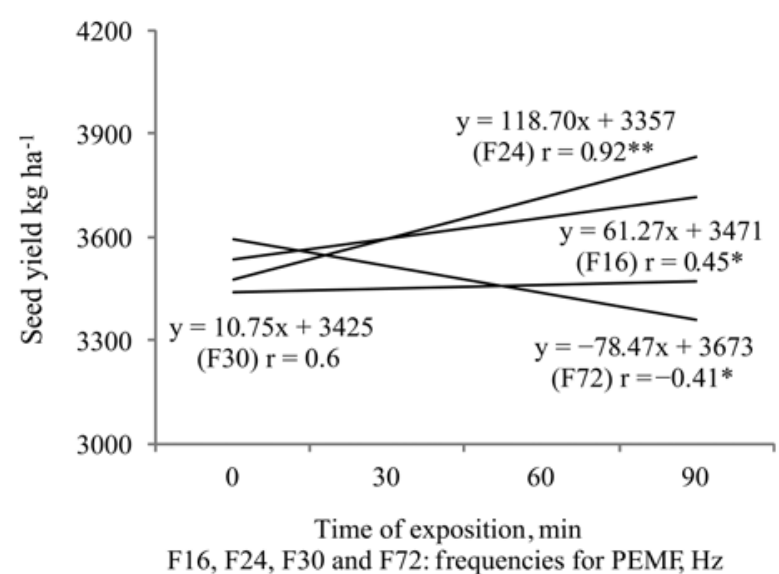

Figure 10. The effect of pulsed electromagnetic waves on soybean seed yield in 2013 
plants could easily overcome daily stress factors, such as fluctuations in the light intensity, temperature variations and water loss during growth (Qi et al., 2015).

\section{Conclusions}

1. Application of pulsed electromagnetic field (PEMF) increased soybean seeds germination in field conditions up to $8.00 \%$ using PEMF frequency $16 \mathrm{~Hz}$ and 30-minute exposure in 2013 and resulted in yield of $960.5 \mathrm{~kg}$, i.e. $21 \%$ using PEMF frequency $16 \mathrm{~Hz}$ and 30-minute exposure in 2010, which is a significant increase and a solid basis for introducing this practice, primarily in organic production where with stimulation of seeds is highly limited.

2. On the other hand, this practice can have an inhibitory effect in case a suitable combination of exposure time and frequency is not used. Attention must be placed on the traits of treatment plants.

3. Significant effect of specific study years was also observed. The better results were obtained under more favourable agroecological conditions or in years with rainfall above average.

\section{Acknowledgements}

This paper presents the results of the project TR-31022 "Interdisciplinary approach to developing new varieties and improving growing technology and seed processing of soybean", supported by the Ministry of Education, Science and Technological Development of the Republic of Serbia.

Received 25022017

Accepted 26072017

\section{References}

1. Abina A., Puc U., Cevc P., Jeglič A., Zidanšek A. 2013. Terrestrial and underwater pollution-source detection using electromagnetic multisensory robotic system. Chemical Engineering Transactions, 34: 61-66. https://doi.org/10.3303/CET1334011

2. Aladjadjiyan A. 2007. The use of physical methods for plant growing stimulation in Bulgaria. Journal of Central European Agriculture, 8 (3): 369-380.

3. Bilalis D., Katsenios N., Efthimiadou A., Karkanis A 2012 (a). Pulsed electromagnetic field: an organic compatible method to promote plant growth and yield in two corn types. Electromagnetic Biology and Medicine, 31 (4): 333-343. https://doi.org/10.3109/15368378.2012.661699

4. Bilalis D., Katsenios N., Efthimiadou A., Efthimiadis P., Karkanis A. 2012 (b). Pulsed electromagnetic fields effect in oregano rooting and vegetative propagation: a potential new organic method. Acta Agricultural Scandinavica, section B: Soil and Plant Science, 62 (1): 94-99.

5. Dicu D., Pirsan P. 2014. The effect of electromagnetic waves on Zea mays plants germination. Research Journal of Agricultural Science, 46 (4): 27-33.

6. Hernández Aguilar C., Domínguez-Pacheco A., Carballo C. A., Cruz-Orea R., Ivanov R., López Bonilla J. P., Valcarcel Montanez J. P. 2009. Alternating magnetic field irradiation effects on three genotype maize seed field performance. Acta Agrophysica, 14 (1): 7-17.

7. Finch-Savage W. E., Bassel G. W. 2016. Seed vigour and crop establishment: extending performance beyond adaptation. Journal of Experimental Botany, 67 (3): 567-591.

https://doi.org/10.1093/jxb/erv490
8. Kong F., Chang S. K. C., Liu Z., Wilson L. A. 2008. Changes of soybean quality during storage as related to soymilk and tofu making. Journal of Food Science, 73 (3): 134-144. https://doi.org/10.1111/j.1750-3841.2007.00652.x

9. Kong F., Chang S. K. C. 2009. Statistical and kinetic studies of the changes in soybean quality during storage as related to soymilk and tofu making. Journal of Food Science, 74 (2): 81-89.

https://doi.org/10.1111/j.1750-3841.2009.01058.x

10. Lamanauskas N., Pataro G., Bobinas Č., Šatkauskas S., Viškelis P., Bobinaitè R., Ferrari G. 2016. Impact of pulsed electric field treatment on juice yield and recovery of bioactive compounds from raspberries and their byproducts. Zemdirbyste-Agriculture, 103 (1): 83-90. https://doi.org/10.13080/z-a.2016.103.011

11. Liu B., Liu X. B., Wang C., Li Y. S., Jin J., Herbert S. J. 2010. Soybean yield and yield component distribution across the main axis in response to light enrichment and shading under different densities. Plant, Soil and Environment, 56 (8): 384-392.

12. Macovei A., Garg B., Raikwar S., Balestrazzi A., Carbonera D., Buttafava, A., Bremont, J. F. J., Gill, S. S., Tuteja N. 2014. Synergistic exposure of rice seeds to different doses of $\gamma$-ray and salinity stress resulted in increased antioxidant enzyme activities and gene-specific modulation of TC-NER pathway. BioMed Research International, 170: 780-787. https://doi.org/10.1155/2014/676934

13. Marcos-Filho J. 2015. Seed vigor testing: an overview of the past, present and future perspective. Scientia Agricola, 72 (4): $363-374$.

https://doi.org/10.1590/0103-9016-2015-0007

14. Martínez E., Carbonell M. V., Flórez M., Amaya J. M., Maqueda R. 2009. Germination of tomato seeds (Lycopersicon esculentum L.) under magnetic field. International Agrophysics, 23 (1): 45-49.

15. Miladinov Z., Balešević Tubić S., Đorđević V., Đukić V., Ilić A., Čobanović L. 2014. Effect of soybean seed priming on germination and vigour depending on the seed lot and sowing date. Field and Vegetable Crops Research, 51 (2): 110-115.

16. Milošević M., Vujaković M., Karagić, Đ. 2010. Vigour tests as indicators of seed viability. Genetika, 42 (1): 103-118. https://doi.org/10.2298/GENSR1001103M

17. Moon J.-D., Chung H.-S. 2000. Acceleration of germination of tomato seeds by applying AC electric and magnetic fields. Journal of Electrostatics, 48 (2): 103-114. https://doi.org/10.1016/S0304-3886(99)00054-6

18. Qi W., Zhang L., Wang L., Xu H., Jin Q., Jiao Z. 2015. Pretreatment with low-dose gamma irradiation enhances tolerance to the stress of cadmium and lead in Arabidopsis thaliana seedlings. Ecotoxicology and Environmental Safety, 115: 243-249. https://doi.org/10.1016/j.ecoenv.2015.02.026

19. Ortiz J., Suarez D., Puentes A., Velasquez P., Santis Navarro A. 2015. Comparison of the effects in the germination and growth of corn seeds (Zea mays L.) by exposure to magnetic, electrical and electromagnetic fields. Chemical Engineering Transactions, 43: 169-174.

20. Palov I., Sirakov K., Kuzmanov E., Zahariev S. 2013. Results of preliminary laboratory studies after pre-sowing electric treatment of pea seeds. Agricultural Engineering, 4: 17-23.

21. Parsi N. 2007. Electromagnetic effects on soybeans. A thesis of Master of Science, University of Missouri, USA, 77 p. https://mospace.umsystem.edu/xmlui/bitstream/ handle $/ 10355 / 5041 /$ research.pdf? sequence $=3$ 
22. Radhakrishnan R., Kumari B. D. R. 2012. Pulsed magnetic field: a contemporary approach offers to enhance plant growth and yield of soybean. Plant Physiology and Biochemistry, 51: 139-144.

https://doi.org/10.1016/j.plaphy.2011.10.017

23. Radzevičius A., Sakalauskienė S., Dagys M., Simniškis R., Karklelienè R., Bobinas Č., Duchovskis P. 2013. The effect of strong microwave electric field radiation on: (1) vegetable germination and seedling growth rate. ZemdirbysteAgriculture, 100 (2): 179-184.

https://doi.org/10.13080/z-a.2013.100.023
24. Shelar V. R., Shaikh R. S., Nikam A. S. 2008. Soybean seed quality during storage: a review. Agricultural Review, 29 (2): 125-131.

25. Vasilevski G. 2003. Perspectives of the application of biophysical methods in sustainable agriculture. Bulgarian Journal of Plant Physiology (spec. iss.): 179-186.

ISSN 1392-3196 / e-ISSN 2335-8947

Zemdirbyste-Agriculture, vol. 104, No. 4 (2017), p. 345-352

DOI $10.13080 / \mathrm{z}-\mathrm{a} .2017 .104 .044$

\title{
Impulsinio elektromagnetinio lauko taikymas siekiant padidinti sojų sèklų daigumą ir derlių
}

\author{
V. Đukić ${ }^{1}$, Z. Miladinov 1 , G. Dozet ${ }^{2}$, M. Cvijanović ${ }^{3}$, M. Tatić ${ }^{1}$, J. Miladinović $^{1}$, \\ S. Balešević-Tubić ${ }^{1}$ \\ ${ }^{1}$ Lauko ir daržo augalų institutas, Serbija \\ ${ }^{2}$ Serbijos John Naisbitt universitetas \\ ${ }^{3}$ Belgrado universitetas, Serbija
}

\section{Santrauka}

Tyrimo tikslas - ištirti impulsinio elektromagnetinio lauko poveikį sojų sėklų daigumui ir derliui priklausomai nuo konkrečių lauko sąlygų, tyrimų metų, poveikio trukmės ir dažnumo. Lauko eksperimentas vykdytas 2010-2013 m. Serbijoje, Novi Sad Lauko ir daržo augalų instituto bandymų lauke. Sojos (Glycine hispida (Moench)) vidutinio ankstyvumo veislès 'Valjevka' sėklos buvo veikiamos impulsiniu elektromagnetiniu lauku naudojant impulsų generatorių ir juostelę. Žemo dažnio (16, 24, 30 ir $72 \mathrm{~Hz}$ ) elektromagnetiniu lauku buvo veikiama 0, 30, 60 ir 90 minučių.

Tyrimų rezultatai parodè, kad šis metodas lauko sąlygomis gali padidinti sėklų daigumą iki 8,0 \%, o derlingumą - 960,5 kg, arba $21 \%$; tai yra reikšmingas padidejimas ir pagrindas taikyti šią praktiką visu pirma sojas auginant ekologiškai, kai sẻklų apdorojimo preparatai gali būti naudojami labai ribotai. Tačiau šio metodo taikymas gali turèti ir slopinamaji poveikị, kai naudojamas nepalankus veikimo trukmès ir dažnumo derinys. Gauti duomenys buvo apdoroti taikant trijų veiksnių bandymų dispersijos analizę, atsižvelgiant ị visus tyrimų metus. Dėl bandymų metų skirtingų meteorologinių sąlygų dispersijos analizė buvo atlikta kiekvienais metais ir buvo nustatytos tirtų savybių koreliacijos.

Reikšminiai žodžiai: daigumas, Glycine hispida, pulsuojančios elektromagnetinès bangos, sėklų derlius. 